\title{
Bias-Free In Situ $\mathrm{H}_{2} \mathrm{O}_{2}$ Generation in a Photovoltaic-Photoelectrochemical Tandem Cell for Biocatalytic Oxyfunctionalization
}

Da Som Choi,,$^{\dagger}$ Hojin Lee,,$^{\dagger}$ Florian Tieves, ${ }^{\dagger}$ Yang Woo Lee, ${ }^{\dagger}$ Eun Jin Son,,$^{\dagger}$ Wuyuan Zhang, ${ }^{\star}$ Byungha Shin, ${ }^{\dagger}$ Frank Hollmann, ${ }^{\star}$ Chan Beum Park ${ }^{*}+$

${ }^{\dagger}$ Department of Materials Science and Engineering, Korea Advanced Institute of Science and Technology, 335 Science Road, Daejeon 34141, Republic of Korea

${ }^{\ddagger}$ Department of Biotechnology, Delft University of Technology, Van der Maasweg 9, 2629HZ Delft, The Netherlands

*Email: parkcb@kaist.ac.kr 


\section{Experimental Procedures}

Materials: The unspecific peroxygenase from Agrocybe aegerita (AaeUPO) was heterologously expressed in Pichia pastoris and purified according to previously published procedure $^{1}$. A concentrated GO solution was purchased from Graphene Supermarket. All of the other chemicals were purchased from Sigma-Aldrich (St. Louis, MO, USA) and used as received.

Preparation of $\mathrm{CN} / \mathrm{rGO}-n$ electrodes: To synthesize $\mathrm{CN} / \mathrm{rGO}-n$ electrode, cyanuric acidmelamine supramolecular assembly was prepared by mixing cyanuric acid $(1.29 \mathrm{~g})$ with melamine $(1.26 \mathrm{~g})$ in $50 \mathrm{~mL}$ of water, and then shaking overnight. Then, the supramolecular powder was collected by centrifugation and followed by drying in a vacuum oven. $100 \mathrm{mg}$ of the supramolecular powder was mixed with a certain amount of the GO solution $\left(5 \mathrm{mg} \mathrm{mL}^{-1}\right)$ with weight $\%$ of $0,0.1,0.2,0.3,0.4$ and 0.5 in $0.2 \mathrm{~mL}$ of ethylene glycol. Subsequently, the obtained precursor paste was coated onto the FTO substrate with a doctor blade technique and then dried for several minutes at a hot plate. Afterward, the thermal calcination was performed at $550{ }^{\circ} \mathrm{C}$ for $4 \mathrm{~h}$ under $\mathrm{N}_{2}$ atmosphere.

Preparation of $\mathrm{FeOOH} / \mathrm{BiVO}_{4}$ electrodes: All synthesis procedures were conducted in air. $0.04 \mathrm{M}$ of $\mathrm{Bi}\left(\mathrm{NO}_{3}\right)_{3} 5 \mathrm{H}_{2} \mathrm{O}$ was dissolved in $0.4 \mathrm{M}$ of $\mathrm{KI}$ aqueous solution $(50 \mathrm{~mL})$ after its $\mathrm{pH}$ was adjusted to 1.7 using $\mathrm{HNO}_{3}$. Then, $20 \mathrm{~mL}$ of ethanol containing $0.23 \mathrm{M}$ of $p$ benzoquinone was slowly added to this solution, and the solution was stirred for a few minutes. To deposit a BiOI layer, a conventional three-electrode cell configuration was applied using FTO glass as a working electrode, $\mathrm{Ag} / \mathrm{AgCl}$ (in $3 \mathrm{M} \mathrm{NaCl}$ ) as a reference electrode and a stainless steel plate as a counter electrode. Electrodeposition of BiOI was performed in the precursor solution for $4 \mathrm{~min}$ at $-0.1 \mathrm{~V}$ (vs. $\mathrm{Ag} / \mathrm{AgCl}$ ). Then, the electrodeposited BiOI film on the FTO was washed several times with deionized water. To convert $\mathrm{BiOI}$ to $\mathrm{BiVO}_{4}$, a certain amount of DMSO solution containing $0.2 \mathrm{M}$ of $\mathrm{VO}(\mathrm{acac})_{2}$ was placed on the $\mathrm{BiOI}$ layer and then the thermal calcination was performed at $450{ }^{\circ} \mathrm{C}$ for $2 \mathrm{~h}$ with a ramping rate of $1{ }^{\circ} \mathrm{C} \mathrm{min}^{-1}$. Excess $\mathrm{V}_{2} \mathrm{O}_{5}$ on the surface of the $\mathrm{BiVO}_{4}$ electrode was removed by soaking in $1 \mathrm{M}$ of $\mathrm{NaOH}$ solution with gentle stirring for $30 \mathrm{~min}$. The resulting $\mathrm{BiVO}_{4}$ photoanodes were rinsed with deionized water and dried under air. Photoassisted electrodeposition of $\mathrm{FeOOH}$ on the $\mathrm{BiVO}_{4}$ electrodes was conducted in a threeelectrode cell configuration using $\mathrm{Ag} / \mathrm{AgCl}$ (in $3 \mathrm{M} \mathrm{NaCl}$ ) as a reference electrode and $\mathrm{Pt}$ mesh as a counter electrode. The $\mathrm{BiVO}_{4}$ electrodes were immersed in a $0.1 \mathrm{M} \mathrm{Fe}\left(\mathrm{SO}_{4}\right)_{2}$ solution with gentle stirring for $20 \mathrm{~min}$ at $0.25 \mathrm{~V}$ (vs. $\mathrm{Ag} / \mathrm{AgCl}$ ) under illumination on the backside of the $\mathrm{BiVO}_{4}$ electrodes via a white LED lamp. After the photodepostion, electrochemical deposition of $\mathrm{FeOOH}$ was performed for $1 \mathrm{~min}$ at $1.2 \mathrm{~V}$ (vs. $\mathrm{Ag} / \mathrm{AgCl}$ ). The resulting $\mathrm{FeOOH} / \mathrm{BiVO}_{4}$ electrodes were rinsed with deionized water and dried under air.

Preparation of CIGS solar cell: CIGS solar cell devices were fabricated according to the literature ${ }^{2}$. CIGS films with a thickness of $1.8 \mu \mathrm{m}$ were deposited on a Mo-coated soda-lime glass substrate by a three-stage co-evaporation process of the elements $\mathrm{Cu}, \mathrm{In}, \mathrm{Ga}$ and $\mathrm{Se}$. The bulk composition of the CIGS films was controlled to tune the $\mathrm{Cu} /(\mathrm{In}+\mathrm{Ga})$ ratio to 0.85 and the $\mathrm{Ga} /(\mathrm{In}+\mathrm{Ga})$ ratio to 0.3 . Afterward, CIGS thin film solar cells with a Mo/CIGS/CdS/i- 
$\mathrm{ZnO} / \mathrm{ZnO}: \mathrm{Al} / \mathrm{Al}$-grid structure were fabricated. A CdS buffer layer with a thickness of $50 \mathrm{~nm}$ was deposited onto the CIGS absorber by a chemical bath deposition process. An undoped i$\mathrm{ZnO}$ intrinsic layer with a thickness of $50 \mathrm{~nm}$ and a $\mathrm{ZnO}$ :Al window layer with a thickness of $350 \mathrm{~nm}$ were deposited on the buffer layer by RF magnetron sputtering. Finally, an Al-grid electrode was deposited by thermal evaporation with an aperture mask at room temperature.

Characterization of Electrodes: The morphologies of electrodes were examined by using an S4800 field-emission SEM (Hitachi High-technologies Co., Japan) and a JEM-3010 TEM (JEOL Ltd., Japan). The elements analyses of the electrodes' surface were conducted by Xray photoelectron spectroscopic analysis (Thermo VG Scientific Inc., UK). The coupling between $\mathrm{CN}$ and rGO was investigated using a Nicolet iS50 Fourier-transform infrared spectroscopy instrument (Thermo VG Scientific, UK).

Photoelectrochemical analysis and $\mathrm{H}_{2} \mathrm{O}_{2}$ generation: The voltammetric analyses of each electrode were carried out in a three-electrode configuration composed of a stainless steel as a counter electrode and $\mathrm{Ag} / \mathrm{AgCl}$ (in $3 \mathrm{M} \mathrm{NaCl}$ ) as a reference electrode with a WMPG100 potentiostat (WonATech Co., Korea) under Xe lamp irradiation (photon flux of $100 \mathrm{~mW}$ $\mathrm{cm}^{-2}$ ) with a $420 \mathrm{~nm}$ cut-off filter and an infrared radiation filter. To construct the tandem configuration, the exposed FTO of the $\mathrm{BiVO}_{4}$ photoanode was connected to the Mo layer of the CIGS PV cell with a cooper wire. The photoelectrochemical $\mathrm{H}_{2} \mathrm{O}_{2}$ generation was conducted in a two-chamber setup connected with a salt bridge without an external bias. $\mathrm{FeOOH} / \mathrm{BiVO}_{4}$ or $\mathrm{FeOOH} / \mathrm{BiVO}_{4} / \mathrm{CIGS}$ in tandem and $\mathrm{CN} / \mathrm{rGO}$ were placed in different reaction vessels. 0.1 M KPi buffer ( $\mathrm{pH}$ 7.0) was used as an electrolyte for both chambers, and in the cathodic chamber, oxygen was bubbled into the electrolyte solution during the reactions.

$\mathrm{H}_{2} \mathrm{O}_{2}$ Quantification: The amount of $\mathrm{H}_{2} \mathrm{O}_{2}$ generated from $\mathrm{CN} / \mathrm{rGO}-n$ cathode was quantified by spectrophotometric assay using 2,2'-azino-bis(3-ethylbenzothiazoline-6-sulfonic acid) (ABTS). The colorimetric reagent $(0.95 \mathrm{~mL}$ of $0.1 \mathrm{M} \mathrm{KPi}$ buffer $(\mathrm{pH} 5.0)$ containing $2 \mathrm{mM}$ ABTS and $2.5 \mathrm{U}$ horseradish peroxidase) and the reaction sample $(0.05 \mathrm{~mL})$ were mixed and then incubated for $10 \mathrm{~min}$ at room temperature. The absorbance of the mixture is monitored at $420 \mathrm{~nm}$ using a V-650 spectrophotometer (JASCO Inc., Japan) and the concentration of $\mathrm{H}_{2} \mathrm{O}_{2}$ was calculated using a calibration curve.

Photoelectroenzymatic reaction and analysis: Photoelectrochemical biocatalysis was conducted in the cathodic chamber of the PEC tandem system with $1 \mathrm{ml}$ of $0.1 \mathrm{M} \mathrm{KPi}$ buffer (pH 7.0) containing $200 \mathrm{nM}$ Aae UPO, $100 \mathrm{mM}$ ethylbenzene at $25^{\circ} \mathrm{C} . \mathrm{O}_{2}$ was bubbled into the reaction medium. $50 \mathrm{mM}$ ethylbenzene was added every 2 hours due to the strong volatility of the reagent. The concentration of $(R)-1$-phenylethanol was analyzed by Gas Chromatography (Agilent Technologies Inc., USA). At intervals, the reaction samples were withdrawn and extracted with ethyl acetate containing $5 \mathrm{mM}$ 1-octanol as internal standard. The organic phase was dried with $\mathrm{MgSO}_{4}$ and centrifuged for $1 \mathrm{~min}$ at $10000 \mathrm{rpm}$. Afterwards, the supernatant $(2 \mu \mathrm{L})$ was injected onto a CP-Chirasil-Dex CB column $(25 \mathrm{~m} \times 0.32 \mathrm{~mm} \times$ $0.25 \mu \mathrm{m})$. The temperature program for analysis of AaeUPO-catalyzed oxyfunctionalization reactions is as follows: (1) Hydroxylation of ethylbenzene: started at $90{ }^{\circ} \mathrm{C}$ (held for $5 \mathrm{~min}$ ) 
and then increased to $110{ }^{\circ} \mathrm{C}$ at $20{ }^{\circ} \mathrm{C} \mathrm{min}-1$ (held for $14 \mathrm{~min}$ ), and increased to $180{ }^{\circ} \mathrm{C}$ at $40{ }^{\circ} \mathrm{C} \mathrm{min}{ }^{-1}$ held at for 2 min more. (2) Hydroxylation of cyclohexane: started at $90{ }^{\circ} \mathrm{C}$ (held for $5 \mathrm{~min}$ ) and then increased to $110{ }^{\circ} \mathrm{C}$ at $20^{\circ} \mathrm{C} \mathrm{min}^{-1}$ (held for $7 \mathrm{~min}$ ). (3) Hydroxylation of propylbenzene: started at $90{ }^{\circ} \mathrm{C}$ (held for $5 \mathrm{~min}$ ) and then increased to $150{ }^{\circ} \mathrm{C}$ at $20{ }^{\circ} \mathrm{C} \mathrm{min}{ }^{-1}$ (held for $7 \mathrm{~min}$ ). (4) Hydroxylation of 4-chloro-ethylbenzene: started at $90{ }^{\circ} \mathrm{C}$ (held for $5 \mathrm{~min}$ ) and then increased to $130{ }^{\circ} \mathrm{C}$ at $20{ }^{\circ} \mathrm{C} \mathrm{min}^{-1}$ (held for $10 \mathrm{~min}$ ). Details of gas chromatograph are shown in Figure S13-18. 

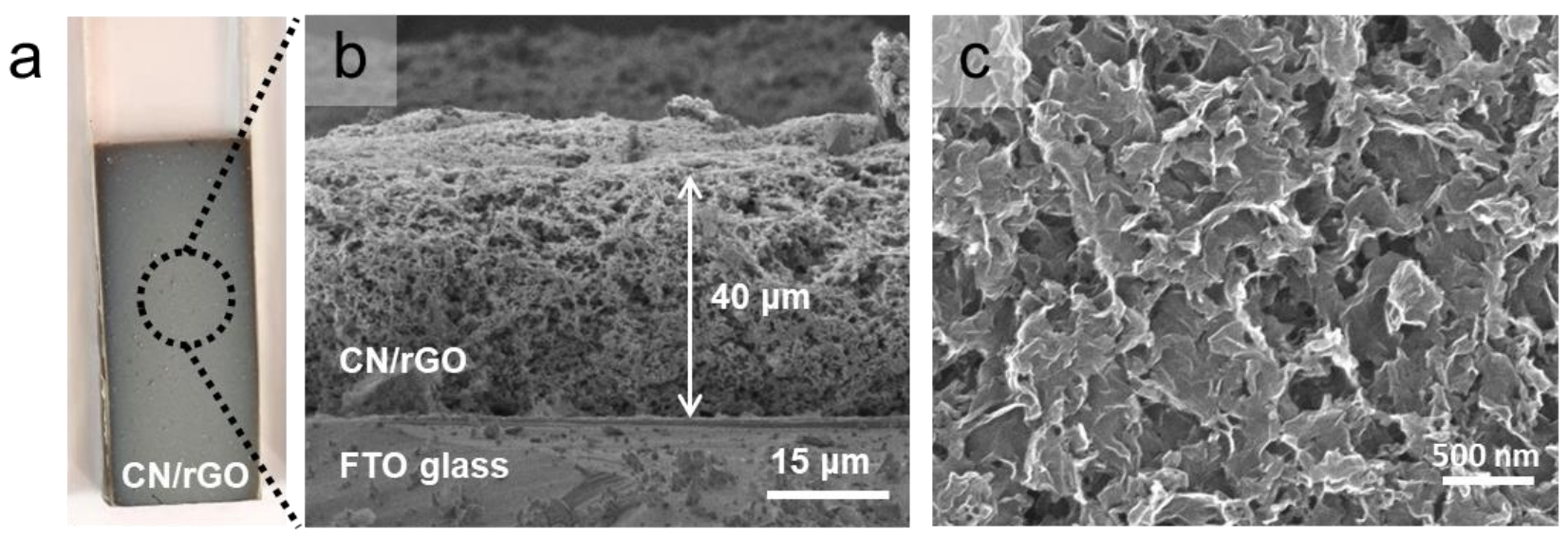

Figure S1. (a) Digital photo of a CN/rGO-0.2 hybrid electrode. (b) Cross-sectional and (c) top-view SEM images of $\mathrm{CN} / \mathrm{rGO}-0.2$ electrode.

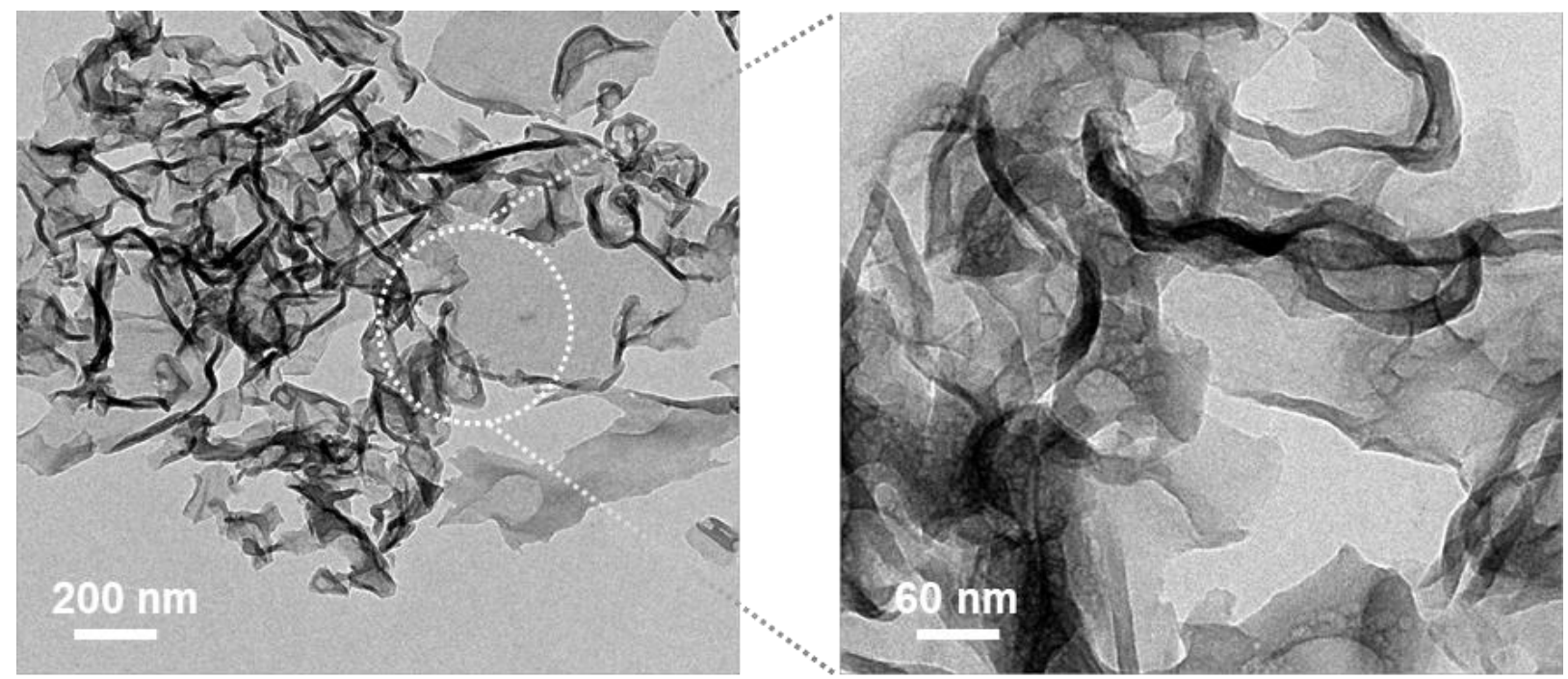

Figure S2. TEM images of CN/rGO-0.2 hybrid electrode at different zoom scales. 

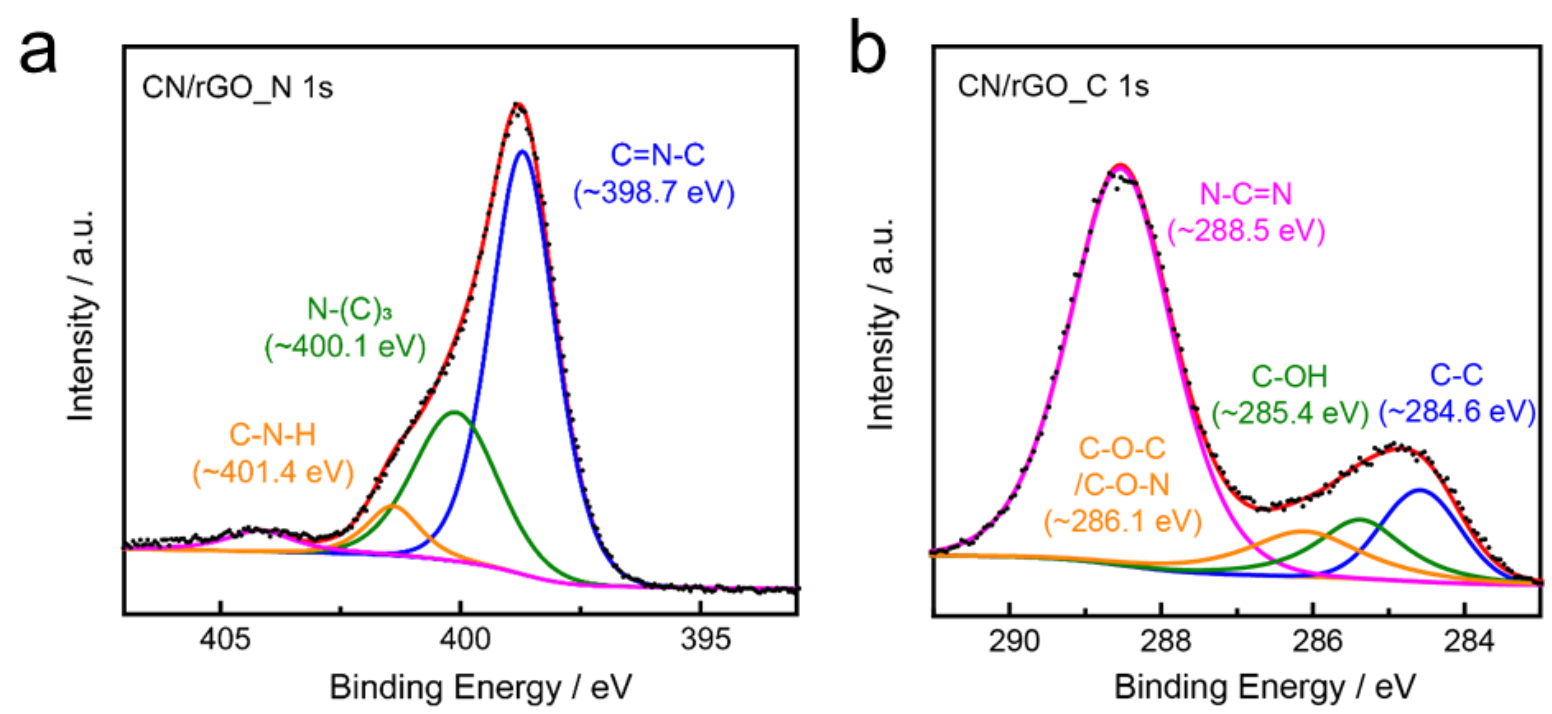

Figure S3. Deconvoluted XPS spectra for (a) N1s region and (b) C1s region of the CN/rGO0.2 film.
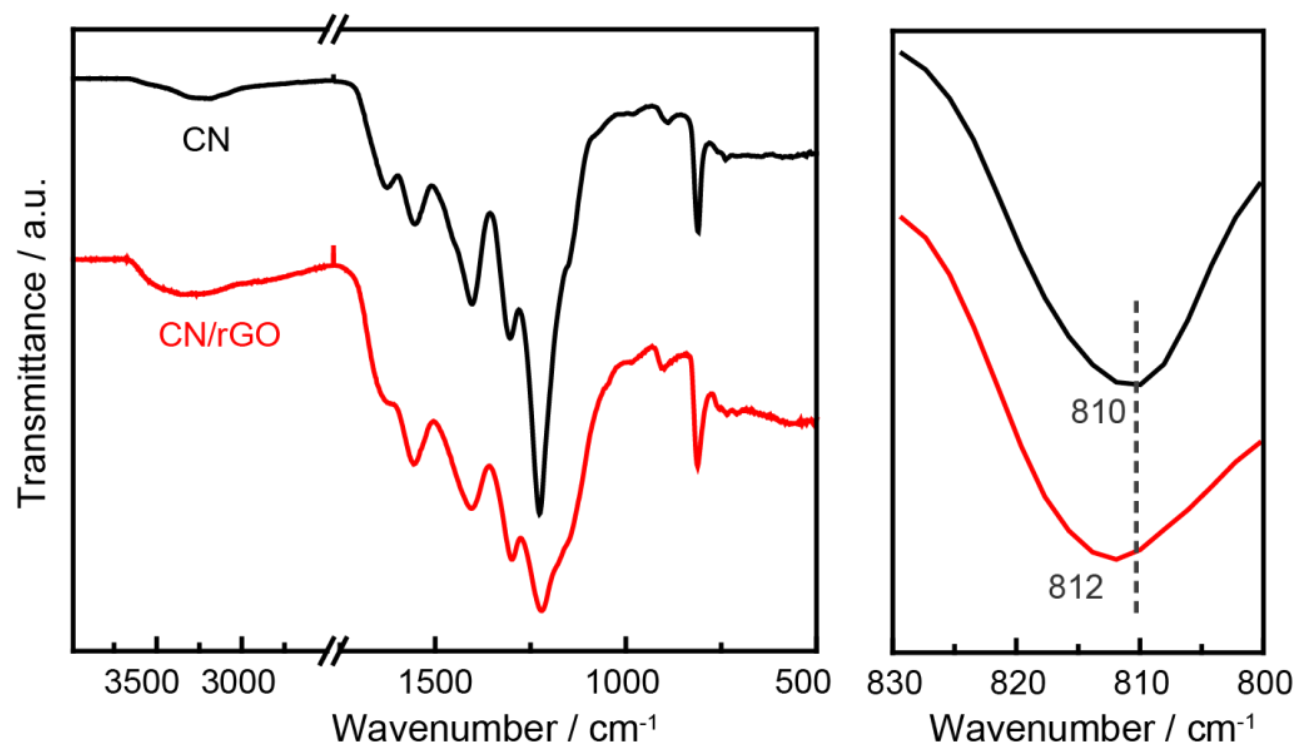

Figure S4. FTIR spectra of $\mathrm{CN}$ and $\mathrm{CN} / \mathrm{rGO}-0.2$ film. A shift of the breathing mode of the triazine unit from 810 to $812 \mathrm{~cm}^{-1}$ was observed due to the strong interaction between $\mathrm{CN}$ and rGO. 

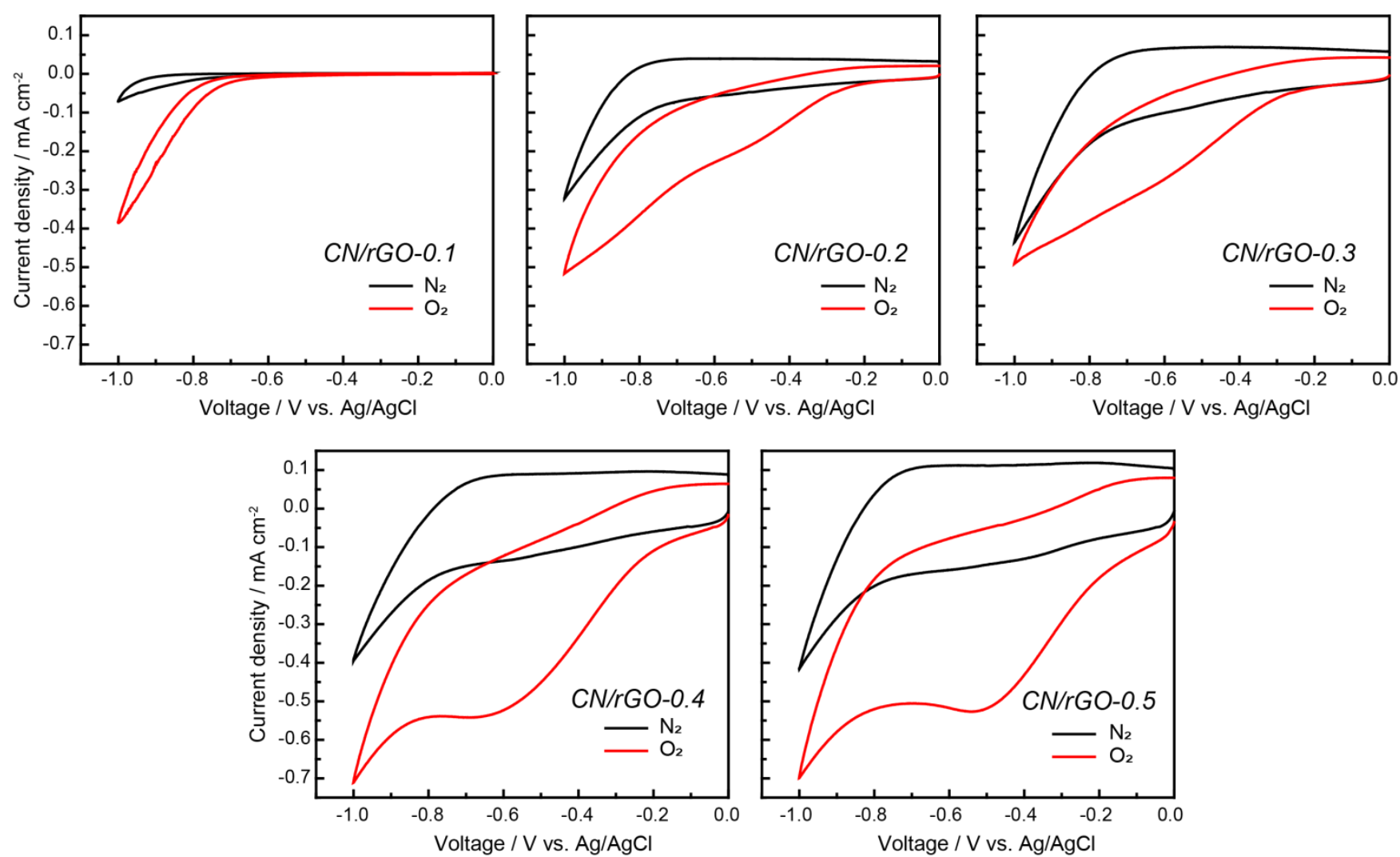

Figure S5. CVs for oxygen reduction at the $\mathrm{CN} / \mathrm{rGO}-n$ electrodes in the $\mathrm{N}_{2}$ - or $\mathrm{O}_{2}$-saturated phosphate buffer $(0.1 \mathrm{M}, \mathrm{pH} 7.0)$ at a scan rate of $50 \mathrm{mVs}^{-1}$. All electrodes had geometrical surface area of $2 \mathrm{~cm}^{2}$.

a

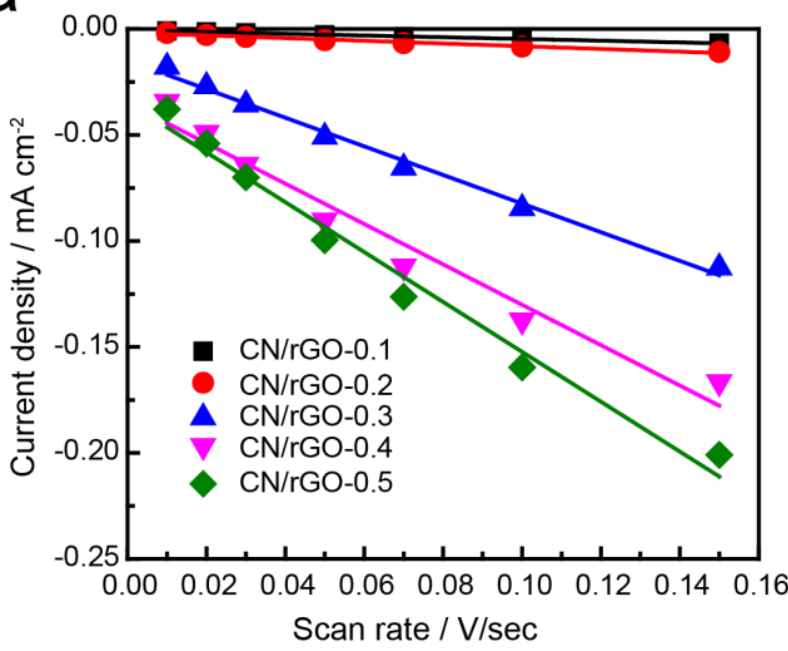

b

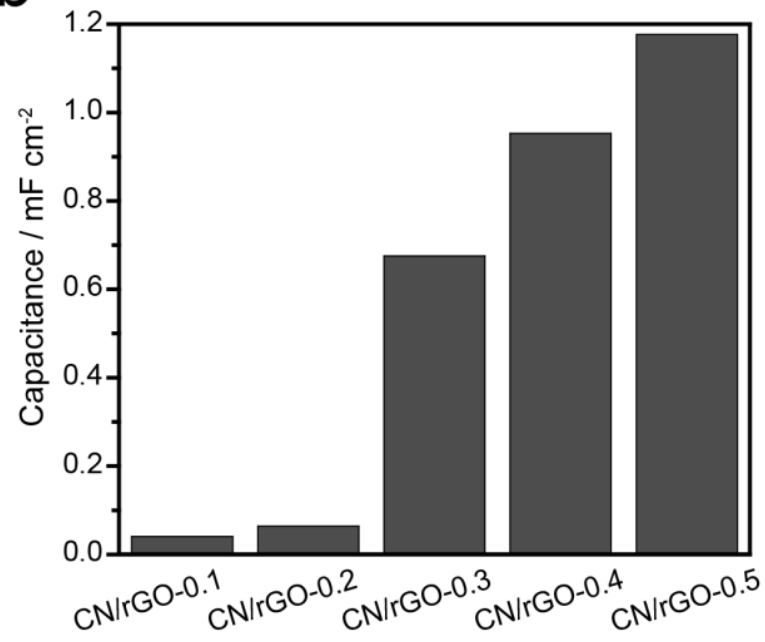

Figure S6. (a) The cathodic charging currents of $\mathrm{CN} / \mathrm{rGO}-n$ electrode measured at $-0.25 \mathrm{~V}$ vs. $\mathrm{Ag} / \mathrm{AgCl}$ as a function of scan rate in a $\mathrm{N}_{2}$ saturated 0.1 M KPi buffer ( $\mathrm{pH}$ 7.0). (b) Doublelayer capacitances values of $\mathrm{CN} / \mathrm{rGO}-n$ electrodes. All electrodes had a geometrical surface area of $2 \mathrm{~cm}^{2}$. 

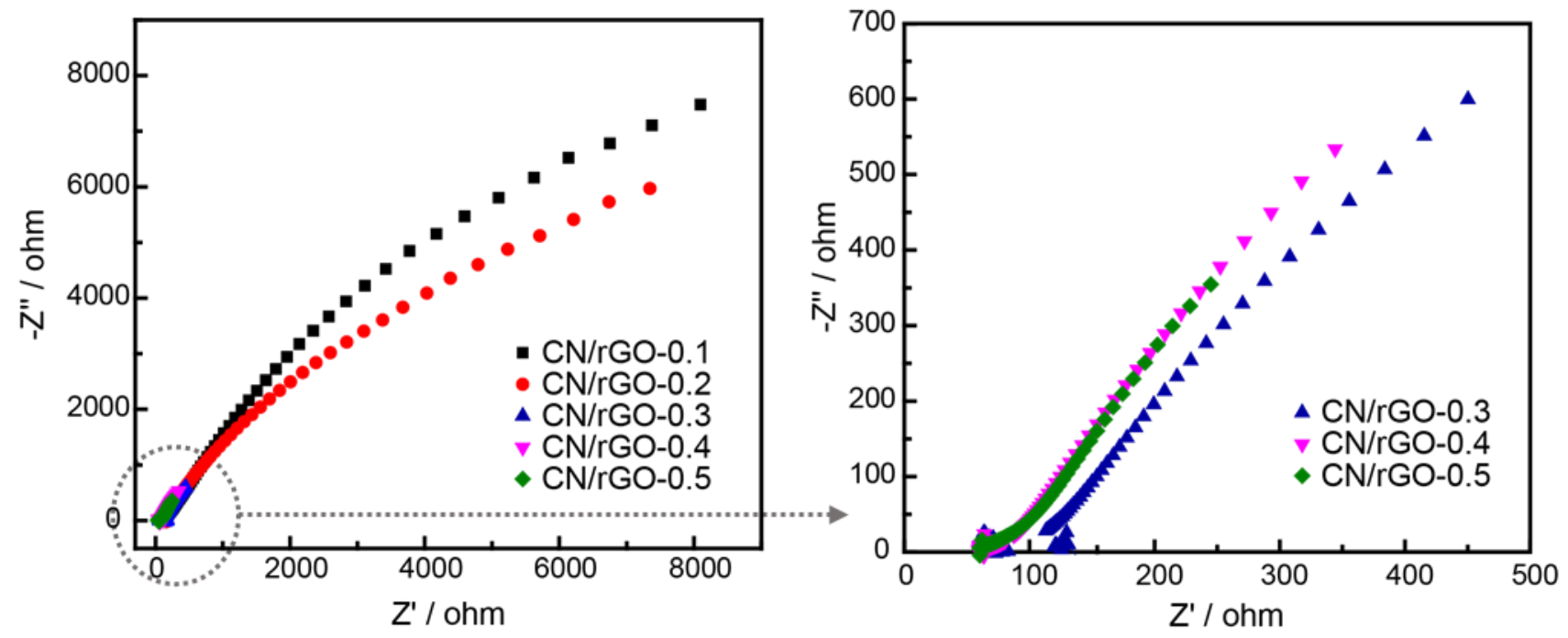

Figure S7. High-frequency parts of Nyquist diagrams of $\mathrm{CN} / \mathrm{rGO}-n(n=0.3,0.4$ and 0.5$)$ electrodes measured in $0.1 \mathrm{M} \mathrm{KPi}$ buffer $(\mathrm{pH} 7.0$ ) at an applied bias of $-0.3 \mathrm{~V}$ ( $\mathrm{vs} . \mathrm{Ag} / \mathrm{AgCl}$ ).

a

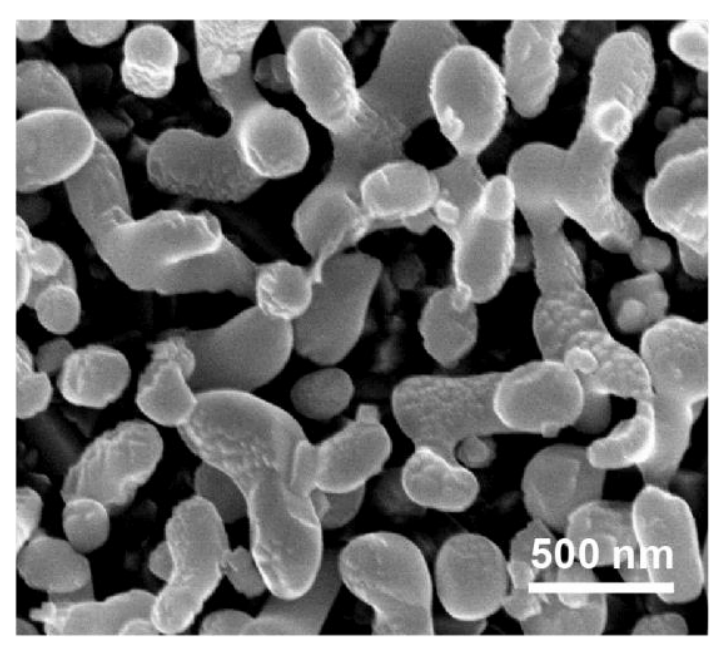

b

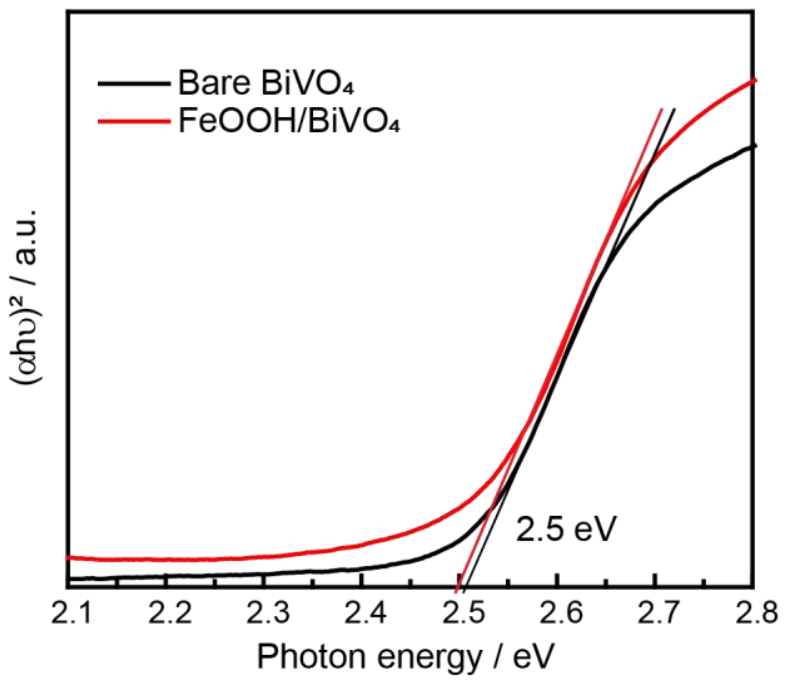

Figure S8. (a) SEM image of $\mathrm{FeOOH} / \mathrm{BiVO}_{4}$ photoanode. (b) The optical band gap energy of $\mathrm{BiVO}_{4}(2.5 \mathrm{eV})$ and $\mathrm{FeOOH} / \mathrm{BiVO}_{4}(2.5 \mathrm{eV})$ was calculated from the Tauc plots. 

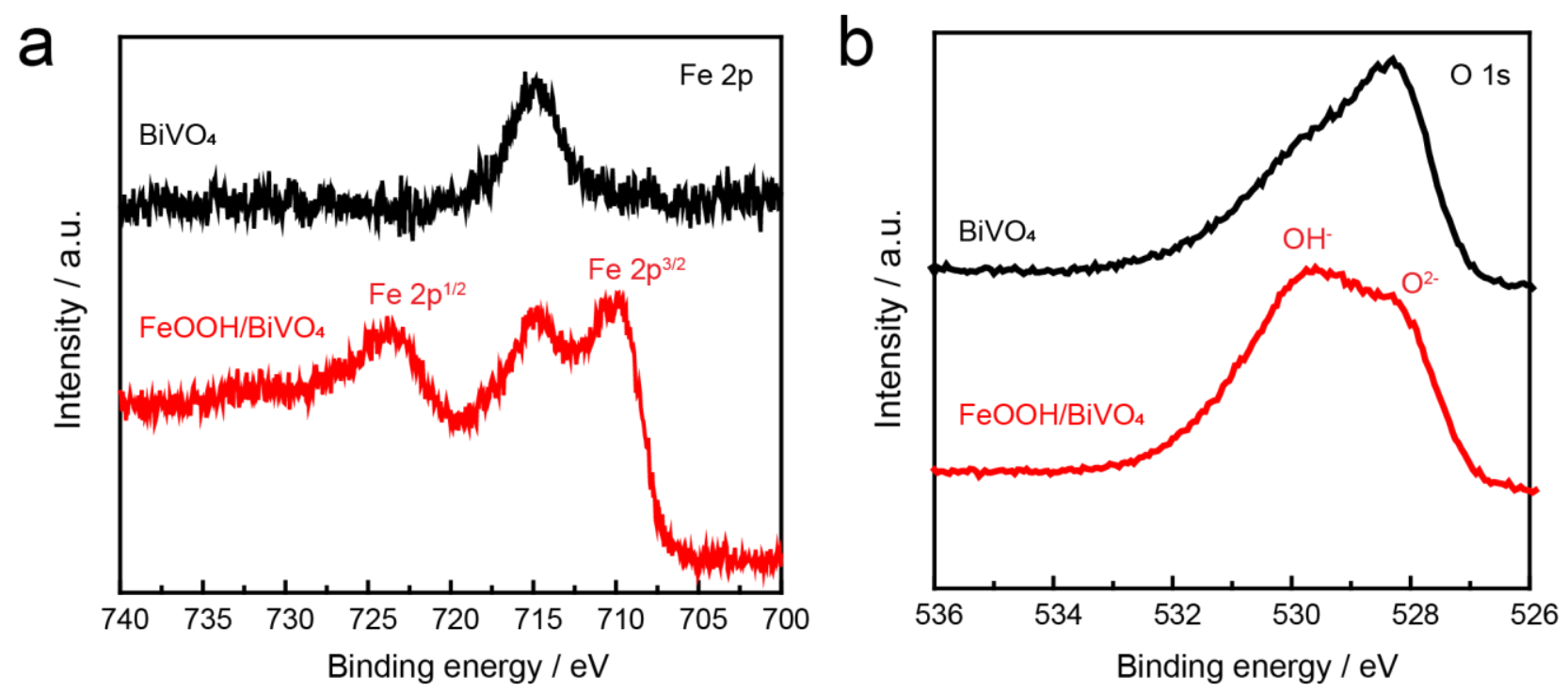

Figure S9. (a) Fe 2p and (b) O 1s XPS spectrum of $\mathrm{BiVO}_{4}$ (black) and $\mathrm{FeOOH} / \mathrm{BiVO}_{4}$ (red) photoanode.

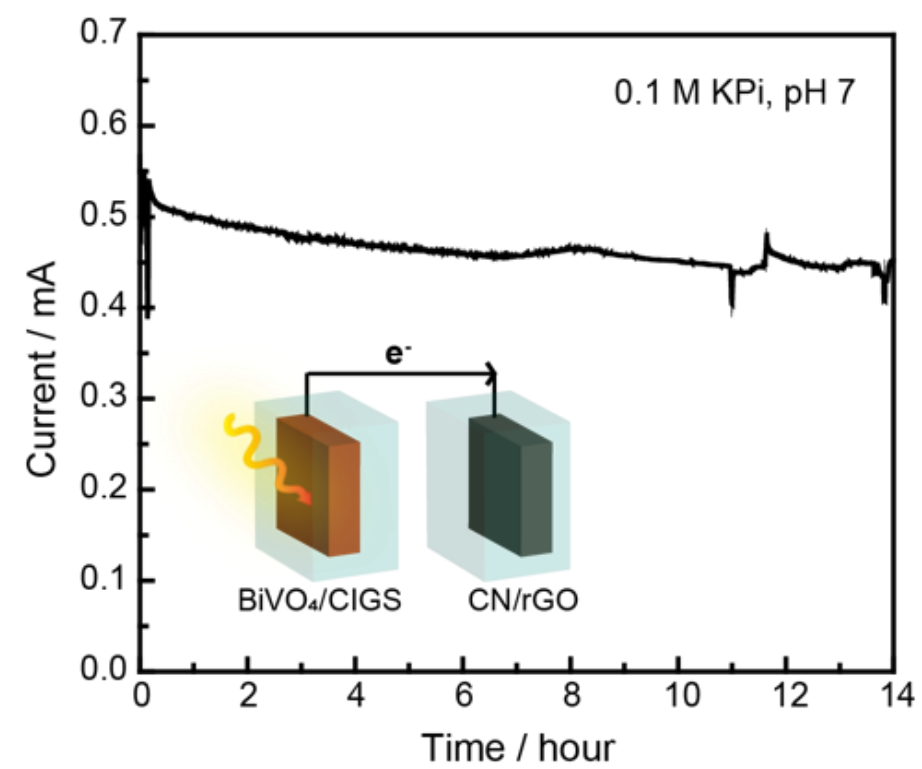

Figure S10. The photocurrent of the PEC tandem system (i.e., $\mathrm{FeOOH} / \mathrm{BiVO}_{4} / \mathrm{CIGS}$ solar cell in tandem and $\mathrm{CN} / \mathrm{rGO}-0.5$ cathode) in a two-compartment configuration (inset figure) connected by a salt bridge under 1 sun illumination. 


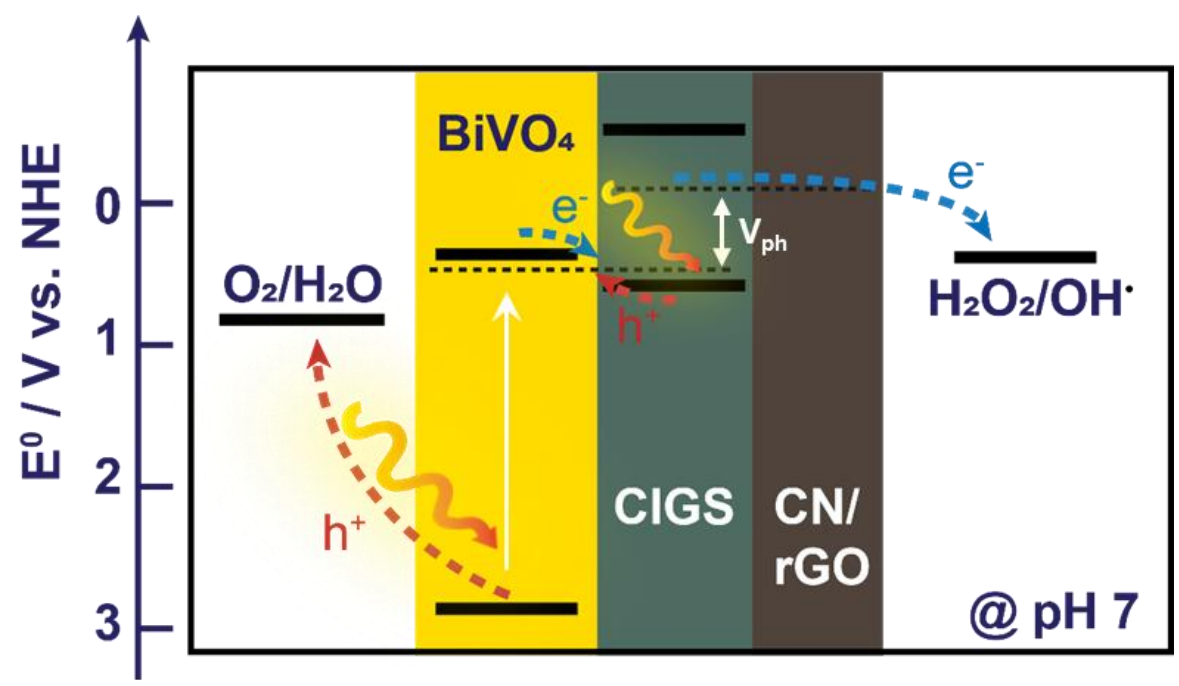

Figure S11. Schematic diagrams of the energy band structure of the PEC tandem system (i.e., $\mathrm{FeOOH} / \mathrm{BiVO}_{4} / \mathrm{CIGS}$ solar cell in tandem and $\mathrm{CN} / \mathrm{rGO}$ electrode) with respect to the $\mathrm{NHE}$ scale at $\mathrm{pH}$ 7. Hydroxyl radicals are possibly generated through $\mathrm{H}_{2} \mathrm{O}_{2}$ reduction in the PEC tandem system.

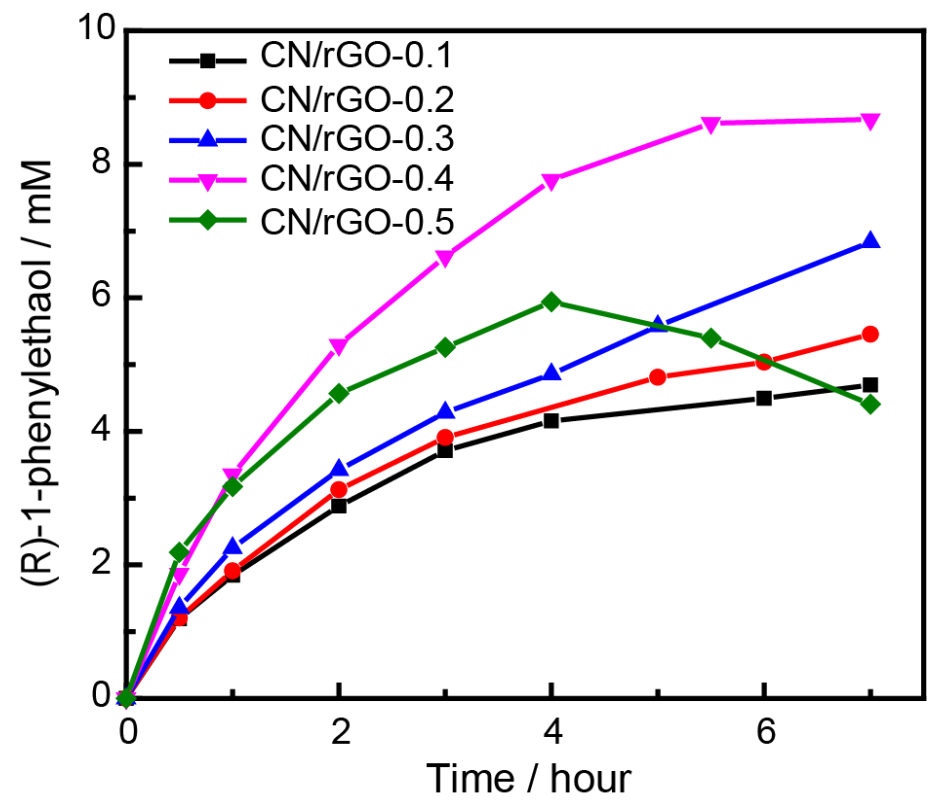

Figure S12. Time profiles of bias-free photoelectroenzymatic $(R)-1$-phenylethanol formation driven by $\mathrm{FeOOH} / \mathrm{BiVO}_{4} / \mathrm{CIGS}$ tandem cell with $\mathrm{CN} / \mathrm{rGO}-n$ electrodes under light illumination. 


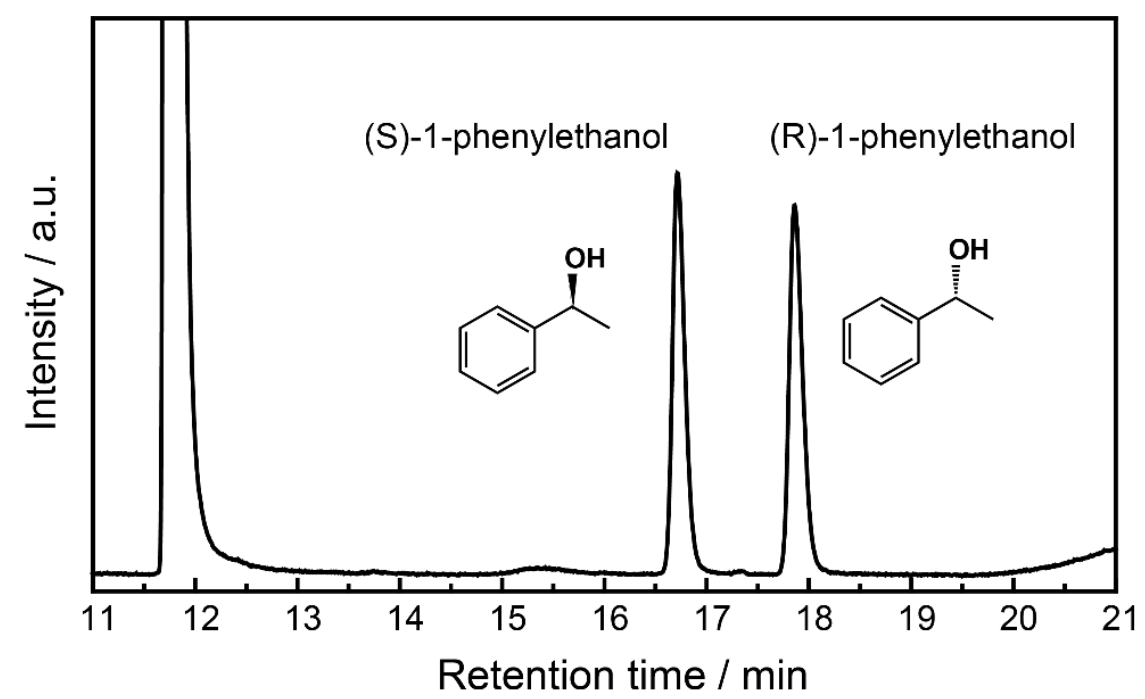

Figure S13. Representative GC chromatogram of racemic 1-phenylethanol.

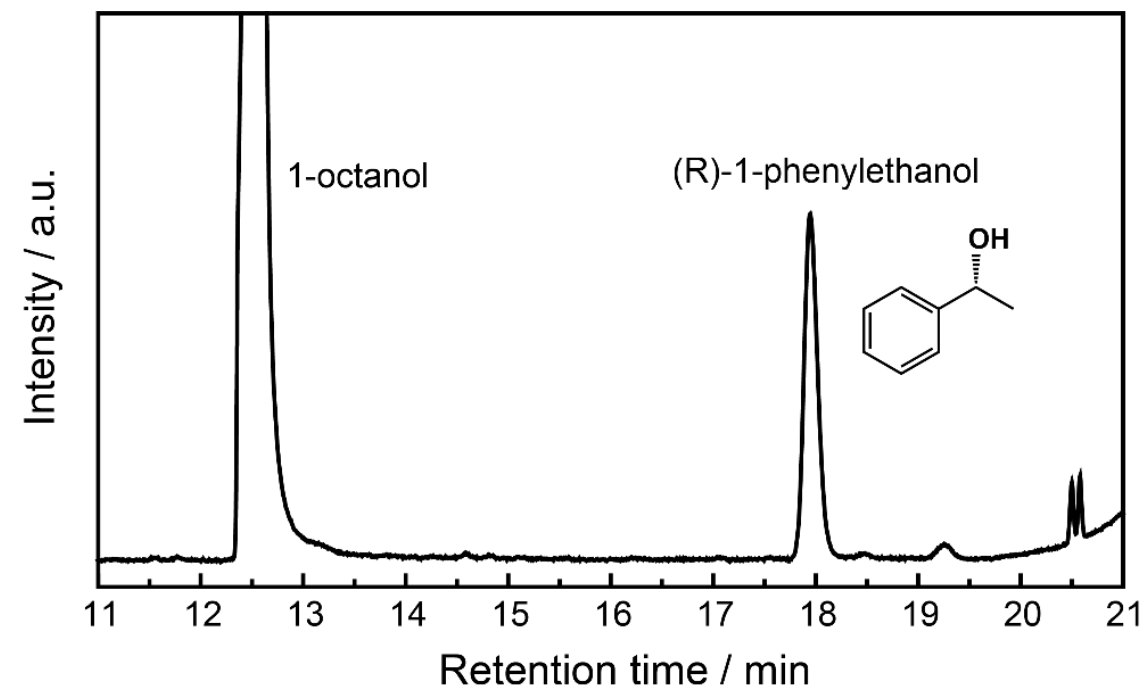

Figure S14. Representative GC chromatogram of AaeUPO-catalyzed hydroxylation of ethylbenzene driven by the proposed tandem PEC system.

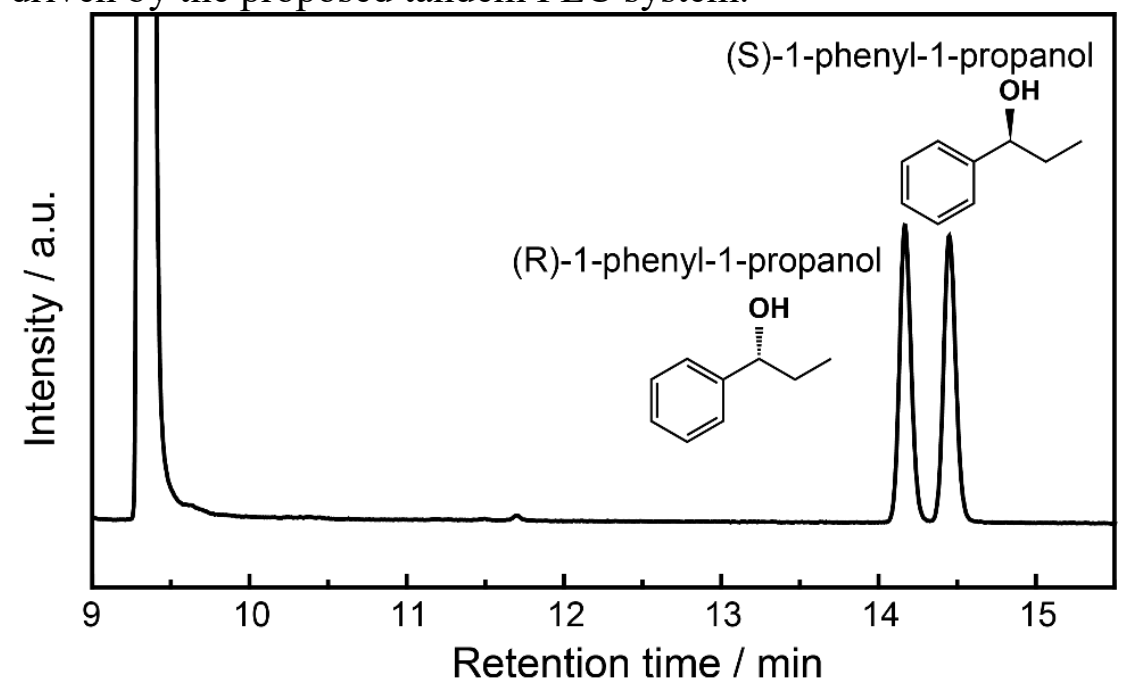

Figure S15. Representative GC chromatogram of racemic 1-phenyl-1-propanol. 


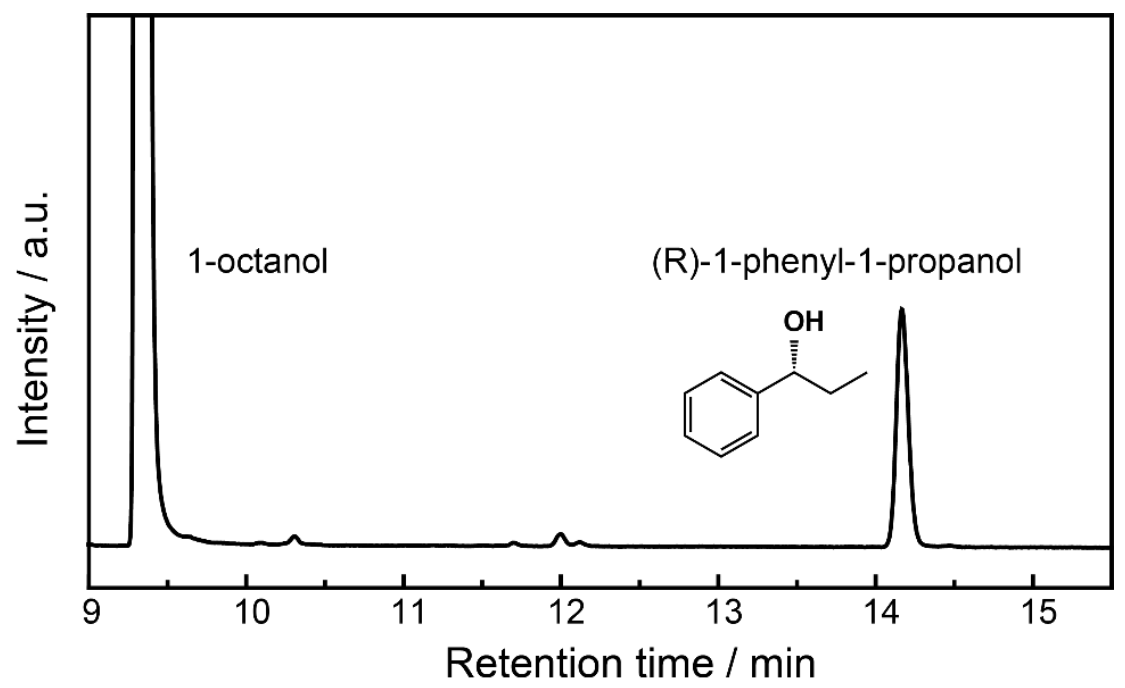

Figure S16. Representative GC chromatogram of AaeUPO-catalyzed hydroxylation of propylbenzene driven by the proposed tandem PEC system.

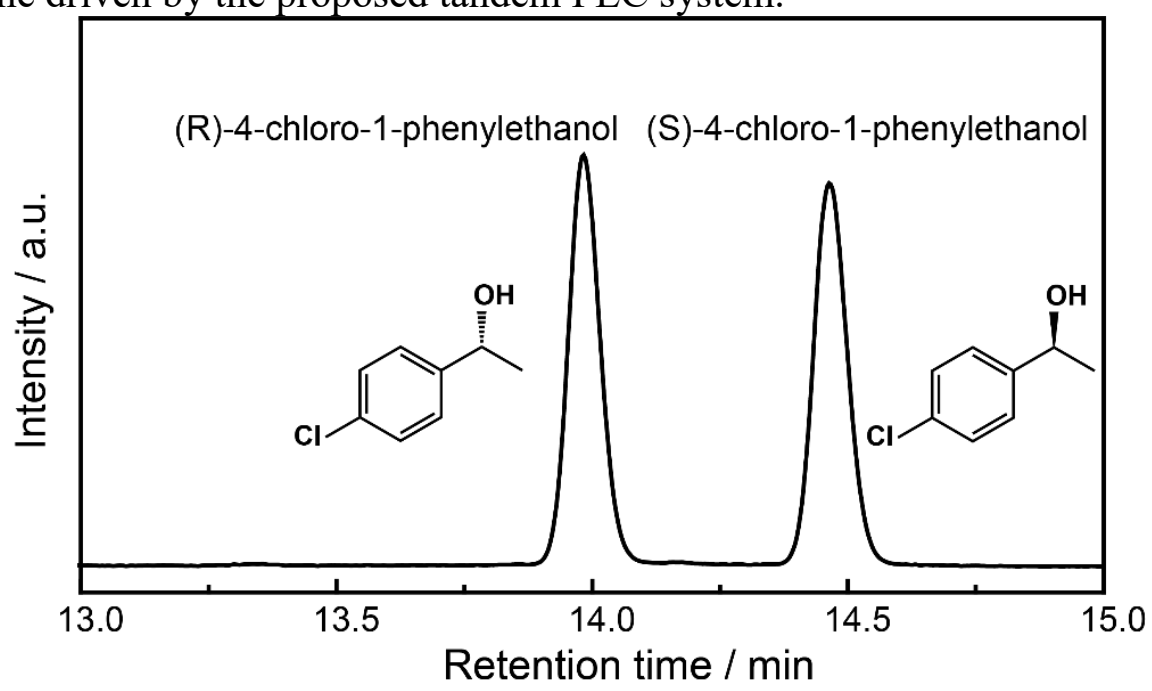

Figure S17. Representative GC chromatogram of racemic 4-chloro-1-phenylethanol.

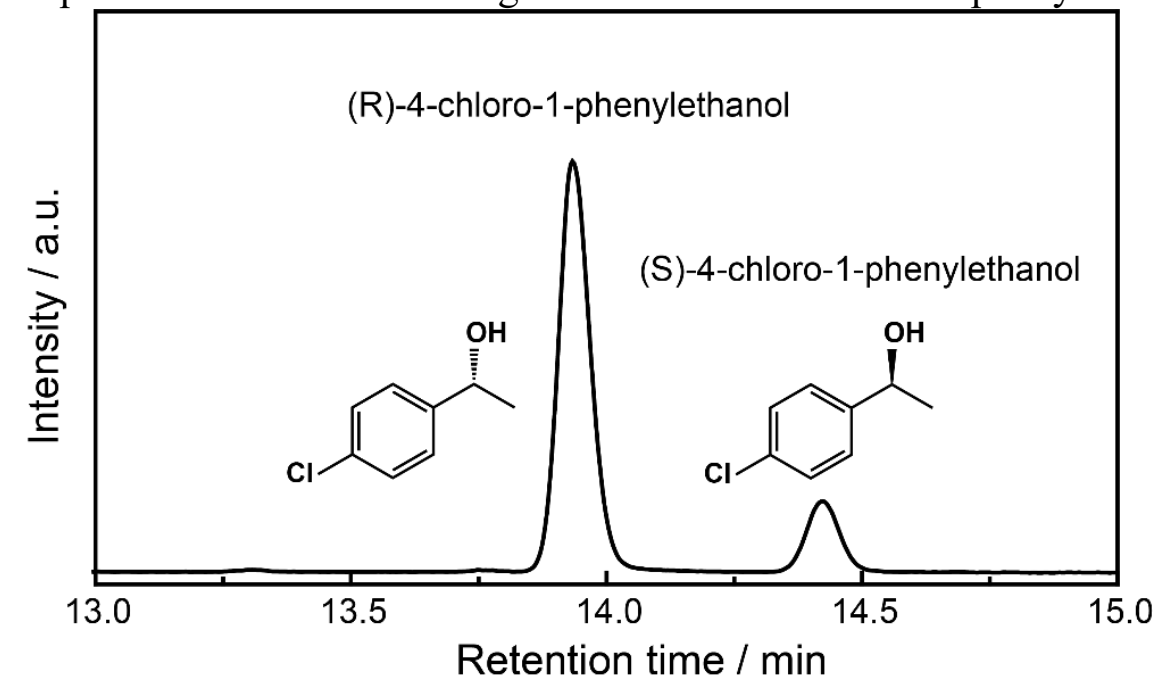

Figure S18. Representative GC chromatogram of AaeUPO-catalyzed hydroxylation of 4chloro-ethylbenzene driven by the proposed tandem PEC system 
Table S1. AaeUPO-catalyzed oxyfunctionalization reactions driven by the proposed tandem PEC platform ${ }^{a}$

Substrate

${ }^{a}[$ Aae UPO $]=200 \mathrm{nM}$, [substrate $]=100 \mathrm{mM}$ in a phosphate buffer $(100 \mathrm{mM}, \mathrm{pH} 7.0)$ under visible light illumination $(\lambda>420 \mathrm{~nm}), 25^{\circ} \mathrm{C}$. Initial TOF and TTN were determined at 30 $\min$ and $6 \mathrm{~h}$ of reaction, respectively. N/A, not applicable. ${ }^{b}$ The value containing overoxidation product (4'-chloroacetophenone of $2.2 \mathrm{mM}$ ).

\section{Reference}

(1) Molina-Espeja, P.; Ma, S.; Mate, D. M.; Ludwig, R.; Alcalde, M., Tandem-Yeast Expression System for Engineering and Producing Unspecific Peroxygenase. Enzyme and Enzyme Microb. Technol. 2015, 73-74, 29-33.

(2) Kim, S. T.; Larina, L.; Yun, J. H.; Shin, B.; Ahn, B. T., Surface Passivation and Point Defect Control in $\mathrm{Cu}(\mathrm{In}, \mathrm{Ga}) \mathrm{Se}_{2}$ Films with a $\mathrm{Na}_{2} \mathrm{~S}$ Post Deposition Treatment for Higher Than 19\% CIGS Cell Performance. Sustain. Energy Fuels 2019, 3, 709-716. 